ISSN 1412-2936

EISSN 2549-7308

\title{
PENGARUH CUACA TERHADAP STABILITAS HARGA IKAN DI DESA KURAU
}

\author{
Jaka Anggara ${ }^{1}$ \\ Jakaanggara98@gmail.com \\ Muhammad Ricky ${ }^{2}$ \\ muhammadricky.ubb@gmail.com \\ Universitas Bangka Belitung
}

\begin{abstract}
ABSTRAK
Cuaca adalah keadaan atmosfer secara keseluruhan pada suatu saat, termasuk perubahan, perkembangan, dan menghilangnya suatu fenomena (Wold Climate Conference, 1979). Mengenai perubahan cuaca memiliki pengaruh besar terhadap stabilitas harga dan kehidupan masyarakat yang berprofesi sebagai nelayan serta penurunan harga ikan. Sebagai contoh dari perubuhan cuaca yang kurang menguntungkan bagi para nelayan adalah ketika gelombang laut tinggi dengan terjangan ombak yang besar membuat para nelayan tidak bisa melakukan aktvitas mereka dalam menangkap ikan seperti hari biasanya, tetapi ada juga nelayan yang nekat untuk pergi melaut, namun hasil tangkapan yang mereka dapat tidak banyak seperti hari-hari biasanya. Jika hasil tangkapan para nelayan mengalami penurunan, hal ini tentunya akan berkaitan dan berdampak langsung pada kehidupan masyarakat yang berprofesi sebagai nelayan di banyak daerah, terutama daerah yang peneliti teliti ini. Tujuan dari penelitian ini adalah agar dapat mengetahui seberapa besar pengaruh cuaca terhadap stabilitas harga ikan yang berada di pasar.

Berdasarkan penelitian yang dilakukan di Desa Kurau, selain cuaca berbengaruh terhadap jumlah kuantitas ikan yang didapat oleh para nelayan, cuaca juga sangat berpengaruh terhadap harga ikan yang berada di pasar.

Peneliti melakukan penelitian ini menggunakan metode kualitatif yang kemudian juga dipadukan dengan pendekatan fenomenologi serta dianalisis secara deskriptif guna menjelaskan secara mendalam peristiwa yang terjadi pada masyarakat nelayan di desa Kurau. Hasil yang didapatkan pada penelitian ini menyebutkan bahwa benar perubahn cuaca memiliki pengaruh yang cukup besar terhadap stabilitas harga ikan, bahwakan berimbas pada kehidupan perekonomian nelayan.
\end{abstract}

Kata kunci: nelayan, perubahan cuaca, stabilitas harga 
ISSN 1412-2936

EISSN 2549-7308

\section{PENDAHULUAN}

Indonesia merupakan negara kepulauan (archipelagic state) terluas di dunia dengan jumlah pulau sebanyak 17.504 buah dan panjang garis pantai mencapai $104.000 \mathrm{~km}$ (Bakosurtanal, 2006)(Book, 2014).

Menurut Daryanto: 2007 dalam Irwanto 2015, ia menjelaskan bahwa sumber daya yang ada pada sektor perikanan merupakan salah satu sumber daya yang penting bagi hajat hidup masyarakat banyak dan memiliki potensi yang cukup besar untuk dijadikan sebagai penggerak utama (prime mover) ekonomi nasional, hal ini karena indonesia memiliki keeayaan bawa laut yang snagat besar. Pendapatnya ini didasari oleh beberapa kenyataan yaitu pertama, Indonesia memiliki sumber daya perikanan yang besar baik ditinjau dari kuantitas maupun diversitas. Kedua, Industri di sektor perikanan memiliki keterkaitan dengan sektor-sektor lainnya. Ketiga, Industri perikanan berbasis sumber daya nasional atau dikenal dengan istilah national resources based industries, dan keempat Indonesia memiliki keunggulan (comparative advantage) yang tinggi di sektor perikanan sebagimana dicerminkan dari potensi sumber daya yang ada dan dimiliki oleh banyak daerah di Indonesia. Indonesia merupakan negara yang dikelilingi laut. Luas lautan yang ada wilayah teritorial di Indonesia lebih besar dibanding daratannya. Apalagi negara kita adalah negara kepulauan,yang terdiri atas beribu pulau dan diantara pulau-pulau itu dibatasi oleh selat dan laut yang sangat luas. Indonesia disebut sebagai negara maritim, artinya Indonesia disebut negara kepulauan karena dua pertiga wilayahnya berupa lautan. Sebagai negara kepulauan, bangsa kita memiliki sumber daya alam kelautan yang sangat luas. Lautan itu sendiri memiliki kekayaan luar biasa. Dari lautan itu, kita bisa mengambil ikan atau biota laut lainnya, termasuk jenis kerangkerangan, kepiting, udang, cumicumi, ganggang laut atau rumput laut, dan juga garam (Ambarjaya, 2008: 4 dalam Julindri Dkk, 2016).

Tidak heran jika Indonesia memiliki kawasan teritorial laut yang luas. Kekayaan alam laut dan perikanan merupakan sektor penting dalam bidang perekonomian, selain pada tingkat nasional perikanan juga menjadi sektor penting pada perekonomian masyarakat yang berprofesi sebagai nelayan sehingga perlu untuk diperhatikan secara mendalam. Persaolan tantang perubahn cuaca ini memamng sudah menjadi perbincangan hangat baik di rana nasional maupun global, hampir diseluruh wilayah yang ada di berbagai belahan dunia, cuaca memang menajdi kendala besar bagi para nelayan terutama beberapa tahun terakhir yang banyak terjadi kecelakan kapal yang diakibatkan gelombang tinggi dan angin.

Di balik kekayaan alam laut yang melimpah, bukan berarti tidak ada masaah dibalikkya, tidak jarang para nelayan yang menangkap mengalami banyak kendala dalam menjalankan profesi atau pekerjaan emreka ketika melaut, ditambah lagi dengan permasalahan-permasalahan yang kerap terjadi dilingkungan nelayan seperti harga ikan yang kerap mengalami perubahan, peralatan serta teknologi yang digunakan dalam melaut dan juga kondisi cuaca sering mengalami perubahan yang kemudian ikut mempengaruhi hasil tangkapan, terlebih lagi ketika perubahan cuaca ini terjadi dalam jangka waktu yang lama hal ini akan mengakibatkan perubahan suhu yang sangat ekstrim dan berdampak lanjutan bagi nelayan. Sebagai contoh dari perubuhan cuaca yang kurang menguntungkan bagi para nelayan adalah ketika gelombang laut tinggi dengan terjangan ombak yang tinggi akan memuat para nelayan tidak bisa melakukan aktvitas mereka dalam menangkap ikan seperti hari biasanya, tetapi ada juga nelayan yang nekat untuk pergi melaut, namun hasil tangkapan yang mereka dapat tidak banyak seperti hari-hari biasanya. Jika 
hasil tangkapan para nelayan mengalami penurunan, hal ini tentunya akan berkaitan dan berdampak langsung pada kehidupan masyarakat yang berprofesi sebagai nelayan di banyak daerah, kerena jumlah tangkapan ikan yang didapat oleh para nelayan akan mempengaruhi pertumbuhan ekonomi masyarakat. Selain itu nelayan memang merupakan profesi dengan penghasilan tidak tetap dan juga tingkat resiko pekerjaan yang tinggi, penghasilan nelayan di dasarkan pada seberapa banyak ikan yang mereka peroleh dan juga harga jual di pasar. Tentanya kita juga mengetahui bahwa harga ikan di pasar kerap kali mengalami perubahan terkadang mengalami keaikan dan juga penurunan sesuai dengan kondisi ekonomi dan pemintaan masyarakat.

Terdapat juga beberapa faktor lainnya yang mempengaruhi stabilitas harga ikan dan perekonomian masyarkat. Tulisan ini akan membahas mengenai pengaruh cuaca terhadap stabilitas harga ikan. Adapun bahasan tersebut mencakup beberapa hal, yaitu pengaruh cuaca terhadap hasil tangkapan nelayan, stabilitas harga ikan, pertumbuhan ekonomi masyarakat dan juga upaya dari pihak pemerintah desa dalam meningkatkan pertumbuhan ekonomi masyarakat nelayan di Desa Kurau. Desa kurau merupakan desa dengan sebagian besar masyarakatnya berprofesi sebagai nelayan sehingga aspek perekonomian mereka bergantung pada laut sehingga menarik untuk dibahas dan dilakukan kajian mendalam terhadap kehidupan masyarakatnya. Penelitian mengenai hal ini dilakukan dengan tujuan untuk mengetahui seberapa besar pengaruh yang ditimbulkan oleh perubahan cuaca terhadap hasil tangkapan nelayan dan stabilitas harga ikan. Hal lainnya yang juga perlu diperhatikan adalah bagaimana upaya dari pemerintah desa setempat dalam menstabilkan harga ikan ketika pada kondisi cuaca yang tidak menentu, Hal penting yang sangat penting untuk diketahui oleh pihak pemerintah desa terkait dengan pertumbuhan ekonomi masyarakat, apakah mengalami peningkatan atau penurunan sehingga ada upaya lanjutan yang bisa diambil untuk mengatasi masalah yang terjadi di dalam masyarakat. Tentunya sebagai masyarakat pesisir perubahan cuaca dan harga ikan akan membuat mereka ikut mengaami perubahan sebagai akibat dari perubahan cuaca yang terjadi.

\section{TEORI DAN HIPOTESIS}

Penelitian ini juga melihat beberapa penelitian orang lain yang telah dilakukan sebelumnya untuk dijadikan sebagai bahan referensi untuk tinjauan bagi penelitian yang dilakukan oleh peneliti. Kajian yang membahas tentang permasalahan pengaruh cuaca terhadap stabilitas harga ikan memang sudah begitu banyak baik dalam bentuk buku, artikel, jurnal, maupun hasil penelitian lainnya.

Penelitian yang dilakukan oleh Hasip Irwanto dari Universitas Muhammadiyah Malang. Pada tahun 2015 yang berjudul "Analisis Strategi Sosial Ekonomi Nelayan Terhadap Dampak Fenomena Cuaca Buruk, Terang Bulan, Dan Kenaikan Harga BBM Di Desa Sotabar Kecamatan Pesean kabupaten Pemakasan di Jawa Timur, dalam kajiannya ini ia membahas tentang pola sosial ekonomi masyarakat nelayan ketika menghadapi permasalahan terkait mata pencarian mereka, ia juga menjelaskan bahwa masyarakat nelayan di sana memiliki ketergantungan yang sangat tinggi dengan alam, sehingga ketika tejadi cuaca buruk, terang bulan akan sangat berperngaruh bagi para nelayan. Dalam penelitian ini juga dibahas mengenai adanya cuaca buruk mengakibatkan nelayan yang sebagian besar mengoperasikan kapal-kapal penangkap ikan berukuran di bawah 30 gross ton (GT) tidak dapat melaut. Apabila para nelayan nekat pergi melaut dipastikan akan mengancam jiwa mereka, baik dari terjangan ombak maupun sambaran petir. Perahu nelayan kecil beberapa kali terbalik 
saat mereka nekat melaut ditengah tingginya gelombang laut atau saat kondisi cuaca buruk. Akibatnya mereka terpaksa tidak melaut.

Penelitian lainnya yang juga membahas mengenai persoalan cuaca dan juga para nelayan adalah penelitian yang dilakukan oleh Juliandri, Dkk pada tahun 2016 yang berjudul Analisis FaktorFaktor Yang Mempengaruhi Hasil Tangkapan Nelayan Di Kecamatan Bilato Kabupaten Gorontalo, dalam jurnalnya ini ia menjalaskan bahwa pokok dari kajian yang ia lakukana adalah membahas tentang beberapa hal yaitu selain karena pengaruh dari alam seperti cuaca dan bulan terang, hasil produksi atau tangkapan ikan nelayan juga di pengaruhi oleh beberapa hal lainnya yaitu sarana dan prasarana, SDM serta modal. Serta kemajuan teknogi dalam melaut. Peningkatan jumlah teknologi penangkapan ikan, seperti jumlah perahu penangkapan yang semakin meningkat, maka masyarakat nelayan lokal dituntut untuk dapat mengembangkan teknologi perikanan yang lebih baik lagi melalui budaya lokal supaya mereka tidak tersingkir oleh keberadaan kapal-kapal modern nelayan lainnya. Hal ini diharapkan mampu meningkatkan perekonomian dari masyarakat nelayan di Gorontalo. Dengan kata lain penelitian yang dilakukan oleh Juliandri.

Sedangkan penelitian yang dilakukan oleh Azazi, dkk mereka lebih membahas mengenai analisis dampak yang di timbulkan oleh varibilitas iklim pada pendapatan nelayan. Dalam jurnalnya yang berjudul Analisis FaktorFaktor Yang Mempengaruhi Perubahan Pendapatan Nelayan Akibat Variabilitas Iklim (Kasus: Desa Muara Kecamatan Blanakan Kabupaten Subang) pada tahun 2017, Azazi, dkk menjelaskan bahwa variabilitas iklim seperti curah hujan serta kondisi perairan dengan tinggi gelombang dan angin yang kuat mempengaruhi aktivitas nelayan di laut dalam melakukan operasional penangkapan. Kondisi ini mengakibatkan perubahan pendapatan dari para nelayan. Mereka juga menjelaskan bahwa Nelayan merupakan jenis pekerjaan atau mata pencaharian yang high risk serta pendapatannya tidak menentu. Karena pendapatan para nelayan dihitung berdasarkan hasil yangkapan yang mereka peroleh dikurangi modal yang mereka keluarkan. Dapat disimpulkan bawah jurnal yang ditulis oleh Azazi, ddk mereka berfokus pada varibilitas iklam serta keuntungan yang didapatkan oleh para nelayan dalam pekerjaan mereka mennagkap ikan. Model linear berganda yang digunakan olehnya adalah teknik untuk mengkaji persoalan faktor yang memepengaruhi perubahan pendapatan para nelayan.

Berangkat dari beberapa observasi atas kajian pustaka di atas, tidak bisa dipungkiri bahwa Indonesia adalah Negara dengan penghasilan laut yang melimpah, namun di sisi lain dari kekayaan alam laut dan perikanan yang melimpah terdapat beberapa masalah yang di hadapi oleh para nelayan di berbagai daerah salah satunya di daerah Bangka, khususnya nelayan di desa. Hasil penelitian para peneliti diatas dijadikan rujukan oleh peneliti dalam melakukan penelitian dengan objek serupa, namun dengan sudut pandang dan focus kajian yang berbeda, peneliti mencoba meneliti permasalahan nelayan terkait dampak dari perubahan cuaca terhadap stabilitas harga ikan. Peneliti mencoba mengkaji permasalahan lini dari sudut pandang ekonomi dan sosial. Sehingga pada penelitian ini peneliti lebih fokus pada kondisi perekonomian masyrakatnya, khususnya masyarakat nelayan di Desa Kurau, Bangka Tengah yang bergantung pada cuaca untuk hasil tangkapannya, peneliti berpandangan bahwa cuaca memliki pengaruh yang besar bagi para nelayan terutama untuk hasil tangkapan dan juga harga ikan yang akan ikut mengalami perubahan yang cukup signifikan ketika cuaca buruk.katakanlah 
stabilitasdari harga ikan mengami perubahan. Stabilitas harga ikan adalah pemeliharaan atau penjagaan suatu tingkat harga ikan secara umum yang tidak mengalami perubahan dari waktu ke waktu dalam perekonomian. Hal inilah yang kemudian juga mendasari dilakukannya penelitian ini karena fenomena yang terjadi peneliti melihat bahwa adanya pergeseran harga ikan di pasar yang diakibatkan oleh musim atau perubahan cuaca.

Selain kajian di atas, persoalan ini bisa di kaji dengan menggunakan teori dominasi lingkungan. Teori dominasi lingkungan ini adalah teori yang menjelaskan bagaimana hubungan antara manusia dengan alam, dimana manusia memiliki ketergantungan dengan alam, alam yang memiliki kendali terhadap kehidupan manusia serta manusia tidak mampu menerima amukan alam. Sehingga cocok untuk membahas persoalan antara cuaca dan juga mayarakat nelayan, dimana para nelayan yang cenderung bergantung pada keadaan lingkungan alam untuk melakukan pekerjaan mereka.

Cuaca yang buruk akan membuat para nelayan tidak bisa untuk pergi melaut dengan begitu mereka tidak akan mendapatakan pengahasilan. Terlihat jelas bahwa cuaca memiliki kendali terhadap pekerjaan para nelayan dilaut. Perubahan yang terjad pada cuaca akan memberikan perubahan pula pada pola kehidupan masyarakat nelayan dan juga pertumbuhan ekonomi pasar. Kaitannya dengan pertumbuhan ekonomi pasar adalah, keseimangan dari harga ikan ditentukan oleh para konsumen dan juga harga pasar, ketika cuaca memberikan dampak yang kurang baik pada para nelyaang yang melaut, misalnya ketika terjadi gelombang tinggi dan lainnya, maka para nelayan akan kesulitan mendapatkan ikan. Lalu timbulah peningkatan harga ikan dipasaran karena ketersedian ikan yang mengalami penurunan. Dengan demikian teori ini relevan jika diimpilikasikan pada kasus yang diangkat oleh peneliti yaitu tentang pengaruh perubahan cuaca terhadap stabilitas harga ikan di desa Kurau. Di mana stabilitas dariharga ikan ini akan berpengaruh terhadap kehidupan nelayan dan juga pertumbuhan ekonomi masyarakatnya. Pertumbuhan ekonomi yang dimaksudkan adalah peningkatan kapitas produksi dalam perekonomian baik local maupun nasional.

\section{METODE PENELITIAN}

Mengacu pada persoalan yang diteliti, metode yang digunakan oleh peneliti dalam mengkaji persoalan ini adalah metode kualitatif yang kemudian juga dipadukan dengan pendekatan fenomenologi serta dianalisis secara deskriptif. Sesuai dengan fenomena yang dikaji dalam penelitian ini, pendekatan fenomenologi akan menggali data dan menemukan maksud dari sebuah fenomena, realita, dan pengalaman yang dialami oleh objek yang diteliti, dalam hal ini adalah masyarakat nelayan di Desa Kurau. Pendekatan fenomenologi ini relevan digunakan dalam penelitian ini, dikarenakan peneliti ingin melihat dan mengkaji peristiwa apa saja yang terjadi sebagai akibat dari perubahan cuaca terhadap stabilitas harga ikan. Pendekatan fenomenologi ini digunakan dengan tujuan agar peristiwa yang terjadi dalam keseharian masyarakat nelayan di desa Kurau bisa diketahui secara mendalam, Apakah hanya berpengaruh terhadap stabilitas hagra saja atau ada dampak lain yang di timbulkan oleh perubahan cuaca ini. Setelah data didapatkan dari hasil wawancara yang dilakukan, maka kemudian data akan dianalisis dan dijelaskan secara rinci dan mendalam pada bagian pembahasan sehingga tujuan dari penelitian ini bisa tercapai, yaitu mengetahui seberapa besar pengaruh perubahan cuaca terhadap stabilitas harga ikan. Penelitian ini kemudian akan dijelaskan secara deskriptif dimana peneliti menggambarkan peristiwa yang terjadi di desa Kurau secara detail dan mendalam sehingga pembaca bisa membayangkan 
kondisi yang terjadi. Pada penelitian ini penelti menggunakan dua sumber data. sumber data tersebut adalah sumber data primer dan sumber data sekunder. Sumber data primer di dapat melalui wawancara secara lansung dengan masyarakat di Desa Kurau dan juga pihak pemerintah

\section{HASIL DAN PEMBAHSAN}

Penelitian ini dilakukan pada tanggal 21 april 2019 yang bertempat di Desa Kurau, Kecamatan Koba, Kabupaten Bangka tengah. Peneliti memiih desa kurau sebagai objek kajiannya dikarenakan sebagian besar dari masyarakatnya berprofesi sebagai nelayan. Dalam penelitian ini peneliti desa terkait focus peneitian, sedangkan data sekunder berupa buku-buku, jurnal dan tesis yang membahas hal serupa dan reevan dengan apa yang diteliti oleh peneliti, sehingga mempermudah peneliti memperoleh data tambahan.

mengkaji tentang pengaruhi cuaca terhadap stabilitas harga ikan yang terjadi di desa Kurau. Peneliti mengambil beberapa responden untuk dijadikan sumber data dalam penelitian ini. Responden dipilih secara acak oleh penliti sebanyak sepuluh respnden. Berikut ini adalah daftar nama rensponden yang di wawancarai, table 4.1 :

\section{Tabel 4.1}

Daftar Nama Responden Yang Di Wawancarai

\begin{tabular}{|c|c|c|c|c|}
\hline NO & NAMA & UMUR & PEKERJAAN & ASAL \\
\hline 1 & Dian & 39 & Nelayan & Desa Kurau \\
\hline 2 & Suhardi & 56 & Nelayan & Desa Kurau \\
\hline 3 & Senari & 48 & Nelayan & Desa Kurau \\
\hline 4 & Manu & 41 & Nelayan & Desa Kurau \\
\hline 5 & Untung & 33 & Nelayan & Desa Kurau \\
\hline 6 & Jabar & 27 & Nelayan & Desa Kurau \\
\hline 7 & Suheri & 35 & Nelayan & Desa Kurau \\
\hline 8 & Erik & 31 & Nelayan & Desa Kurau \\
\hline 9 & Inul & 38 & Nelayan & Desa Kurau \\
\hline 10 & Rapinda & 40 & Nelayan & Desa Kurau \\
\hline
\end{tabular}

Kembali pada bahasan utama, sebelum membahas lebih dalam mengenai perubahn cuaca yang berdampak pada perubahan stabilitas harga ikan, maka terlebih dahulu akan dibahas apa itu cuaca dan perubahannya. cuaca merupakan keadaan udah di suatu temapt pada waktu tertentu, cuaca kerap kali mengalami perubahan dari waktu ke waktu. Bahkan adakalahnya perubahan ini tidak bisa di prediksi dan berlansung dalam jagka waktu yang cukup lama. Dalam penelitian ini cuaca muncul sebagai salah satu faktor yang mempengaruhi kehidupan nelayan di wilayah pesisir Desa Kurau terutama menyangkut pekerjaan mereka yang berprofesi sebagai nelayan, di ketahui bahwa nelayan merupakan suatu profesi perkerjaan yang kegiatannya adalah mennagkap ikan dan biota lainnya yang ada di perairan. Mayoritas masyarakat Kurau yang berpofesi sebagai nelayan 
memang memiliki banyak kaitan dengan kondisi cuaca. Perubahan cuaca yang sering terjadi membuat para nelayan sering mengalami kesulitan dalam menangkap ikan di laut ketika kondisi cuaca buruk dan hal ini berdampak juga pada kehidupan nelayan sehari-hari.

Beberapa kondisi cuaca yang kerap membuat para nelayan mengalami kendala dalam pekerjaannya, antara lain adalah intensitas curah hujan yang tinggi, bulan terang, gelombang laut tinggi, badan dan angina kencang. Ditambah lagi perubahan musim yang juga memberikan pengaruh yang cukup besar pada banyak atau tidaknya hasil tangkapan mereka. Faktor lainnya dari cuaca adalah intensitas curah hujan yang tidak dapat diprediksi, membuat pola musim ikan juga mengalami perubahan yang berdampak pada perubahan stabilitas harga ikan yang ada dipasar. Faktor lain yang dimaksudkan juga sebenarnya maaih berhubungan dengan cuaca, seperti misalnya pada musim barat dimana kondisi angin yang berhembus cukup kencang tentunya gelombang laut akan lebih tinggi dari biasanya, kondisi seperti ini membuat para nelayan yang ada di Desa Kurau mau tidak mau harus meliburkan diri menangkap ikan untuk beberapa waktu karena beresiko tinggi pada keselamatan walapun pada saat seperti ini harga ikan akan mengalami peningkatan harga yang cukup signifikan dikarenakan permintaan dari masyrakat mengalami peningkatan.

Tinggi gelombang pada musimmusim seperti ini bisa mencapai dua sampai tiga meter atau lebih pada kondisi yang benar-benar ekstrim tentunya akan sangat beresiko bagi para nelayan yang ingin perfgi melaut, pelihan lainnya adalah mereka menunda pekerjaannya sampai kondisi cuaca memungkinkan mereka untuk pergi melaut, akibatnya adalah jumlah nelayan yang turun kelaut pun akan mengalami penurunan dan sudah bisa dipastikan hasil tangkapan mereka pun akan ikut berkurang karena sedikitnya nelayan yang melaut, bahkan pada kondisi cuaca yang sangat buruk para nelayan akan meliburkan diri secara menyeluruh dan tentunya tidak ada hasil tangkapan untuk jangka waktu tertentu, hal ini akan menyebabkan peningkatan jumlah permintaan pasar dan peningkatan harga ikan. Selain itu didapatkan pula data lapangan bahwa ada beberapa faktor lainnya yang juga menentukan stabilitas dari harga ikan, seperti stabilitas dari harga lada dan karet yang ikut menentukan harga ikan di pasar, apa bila karet dan lada ini mengalami kenaikan harga maka harga ikan juga akan ikut mengalami kenaikan menyesuaikan dengan kondisi perekonomian dari masyarakat luas. Seperti pada wawancara yang dilakukan pada tanggal 21 april 2019, berikut ini penjelasan dari salah satu responden:

"selain cuaca faktor lain yang

juga mempengaruhi harga

ikan di pasar adalah stabilitas

dari harga komuditas

pertanian seperti lada dan

karet. Ketika herga dari

komuditas ini meningkat maka

harga ikan di pasar akan

mengalami kenaikan. Begitu

juga sebaliknya, seperti yang

terjadi saat ini harga ikan

mengalami penurunan,

karena faktor perubahan

cuaca dan juga harga

kouditas lada dan karet

mengalami penurunan".

Dari wawancar di atas dapat dilihat bahwa selain cuaca, ada pula faktor lain yang ikut mempengaruhi harga ikan di pasar, walaupun faktor terbesarnya adalah perubahan cuaca. Karena mampu membuat harga ikan mengalami penurunan setengah dari harga ikan pada tahun sebelumnya. Sehingga data yang didapatkan dari para nelayan setempat menyebutkan bahwa harga ikan mengalami penurunan dari tahun sebelumnya sebanyak $50 \%$ atau setangah dari harga sebelumnya dikarenakan saat ini harga komoditas tersebut murah pada 
beberapa tahun terakhir. Seperti yang disampaikan oleh salah satu rensonden pada saat wawancara pada tanggal 21 april lalu:

"hasil tangkapan kami akan
megalami penurunan terutama
pada bulan april hingga bulan
juni dikarenakan bulan terang
dan ikan juga tidak ada, kami
sebagai nelayan bagan cukup
kesulitan untuk mendapatkan
ikan. Hasil tangkapan kami
bisa menurun kurang lebih
$50 \%$ dari hari biasanya.
Jadipada bulan-bulan ini
pendapatan kami akan turun
walaupun harga ikan dipasar
naik. Percuma juga harga ikan
naik kalo kai para nelayan
kesulitan untuk menangkap
ikan pada waktu bulan terang".
(Senari)

Dari pejelasan Senari dapat diketehui bahwasannya masyarakat yang berprofesi sebagai nelayan di Desa Kurau mengalami kendala pada bulan-bulan tertentu seperti yang terjadi pada periode april hingga juni atau masyarakat Desa Kurau sering menyebutkan bulan-bulan tersebut sebgai bulan apit, pada bulan ini cenderung ikan yang ada hanya sedikit dan sulit untuk di tangkap, dimana hasil tangkapan nelayan akan menurun sebanyak $30 \%$ dari hari-hari biasanya dikarenakan ikan yang susah di dapat pada bulan tersebut disertai bulan terang. Tentunya hasil tangkapan ikan yang menurun ini juga akan berimbas pada harga ikan di pasar yang akan meningkat dan juga permintaan pasar akan lebih banyak dari biasanya. Seperti yang dijelaskan oleh responden diatas bahwa harga ikan memang mengalami peningkatan harga tetapi pada kondisi ini ikan yang sulit untuk didapatkan.

Hal ini juga selaras dengan apa yang disampaikan oleh Dian selaku nelayan lainnya ia juga menjelaskan bahwa baik nelayan bagan maupun nelayan pancing akan sama pendapatnya terkait dengan perubahan cuaca yang memiliki dampak buruk terhdap pekerjaan mereka. Berikut iniadalah argumenyang disapaikan oleh dian:

"penurunan hasil tangkapan
kami juga menurun ketika
bulan terang, bagi kami yang
berprofesi sebagai nelayan
bagan, akan mengalami
penurunan yang cukup
signifikan sebanyak 50\%.
Penurunan ini harus kami akui
memang memberikan
pengaruh yang cukup besar
baik bagi perekonomian kami
yang bekerja sebagai nelayan
dan juga perekonomian
masyarakat luas. Jika tadi
ditanyakan mengapa berimbas
pada perekonomian kami, itu
karena cuaca yang
mempengaruhi hasil dari
tangkapan kami”. (Dian)

Dari penjelasan Dian di atas menjelaskan bahwa masyarakat memang bergantung pada kondisi lingkungan alam, katakanlah mereka memang memiliki ketergantungan terhadap alam terutama cuaca yang menjadi faktor penting dalam pekerjaan mereka, karena pada dasarnya profesi yang mereka tekuni sedikit banyaknya mengandalkan kondisi lingkungan terutama cuaca, sedangkan cuaca sendiri perubahanya cukup sulit untuk diprediksi, hal ini juga berpengaruh pada pola musim ikan yang akan ikut berubah dan perubahan bulan tangkap ikan, seperti misalnya pada bulan tertentu hasil tangkapan nelayan mengalami penurunan dikarena curah hujan yang meningkat dari pada biasanya. Diketahui juga terjadinya penurunan permintaan untuk ikan-ikan yang digunakan dalam pembuatan kerupuk (getas) dimana pada tahun lalu harga ikan mencapai angka $\mathrm{Rp}$ $12.000 / \mathrm{kg}$ maka di tahun ini hanya $\mathrm{Rp}$ 
$6.000 / \mathrm{kg}$ tentunya hal ini mengakibatkan terjadinya penurunan stabilitas dari harga ikan dan juga kelebihan stok ikan yang digunakan untuk pembuatan kerupuk, dikarenakan sudah banyak orang yang menjual bahan utama pembuatan kerupuk ini, terlebih lagi dengan harga yang lebih murah. Pada saat kondisi seperti inilah masyarakat menyayangkan, kurangnya kreativitas dari pemerintah desa untuk melakukan inovasi-inovasi atau memberikan solusi agar ikan-ikan yang digunakan untuk membuat kerupuk (getas) ini bisa di manfaatkan secara optimal. Akan lebih baik jika ikan-ikan yang tidak habis terjual ini di manfaatkan untuk pembuatan kerupuk yang dikelolah lansung oleh pihak desa sebagai bentuk usaha untuk meningkatkan perekonomian masyarakatnya. Seperti yang disampaikan oleh salah satu responden yang bernama Rapinda tentang hal ini:

"kami beberapa kali pernah mengajukan proposal untuk bantuan kepada para nelayan dalam mempermudah pekerjaan. Tapi dari pihak desa sendiri kurang menanggapi dengan apa yang kami sampaikan. Terkait dengan usaha yang coba dibangun oleh pihak desa terkait pemanfataan sisa ikan yang tidak terjual, sejauh ini belaum ada. Seandainya di sini terdapat pabrik kerupuk yang lansung di keloalh oleh pihak desa, mungkin kami para nelayan tidak akan kebingungan menjual ikan yang digunakan sebagai bahan utama produksi kerupuk". (Rapinda).

Seperti yang dijelas sebelumnnya para nelayan yang menangkap ikan untuk pembuatan kerupuk juga mengalami penuruna permintaan pasar dan juga harga yang cukup signifikan mengalami penurunan. Padahal para nelayan menangkap ikan untuk pembuatan kerupuk ini, semata-mata kerena ikan yang dengan harga tinggi seperti tenggiri dan cumi tidak mencukupi target tangkapan. Para nelayan berharap dengan adanya tangkapn ikan kecil-kecil untuk pembuatan kerupuk bisa menutupi kerugian mereka, namun nyatanya harga ikan untuk pembuatan juga mengalami penurunan yang drastis sebanyak $50 \%$. Penjualanpun untuk ikan-ikan kecil ini masih mengalami penurunan dan kerap kali tidak menentu.

Penurunan harga ikan untuk bahan produksi kerupuk ini juga membuat para nelayan tidak bisa berbuat banyak, mau tidak mau mereka akan tetap menjual dengan harag murah dari pada harus terbengkalai dan dibuang begitu saja. Karena jumlah permintaan memang mengalami peningkatan namun jumlah nelayan yang mencari ikan untuk membuat kerupuk ini juga mengalami peningkatan sehingga, akan sulit jika menjual ikan dengan harga yang lebih tinggi. Pada tahun ini harga ikan memang berada pada posisi yang rendah terutama untuk ikan-ikan receh Yang kisaran harganya hanya $\mathrm{Rp} \mathrm{15.000/kg} \mathrm{tentunya}$ ini berefek langsung terhadap pendapatan nelayan, dimana hasil dari penjualan ikan tidak bisa menutupi biaya oprasional yang dikeluarkan dalam menangkap ikan. Saat ini hanya beberapa jenis ikan saja yang harganya cukup tinggi yaitu ikan tenggiri dan sotong/cumi-cumi yang berada pada kisaran harga $R p$ 60.000- Rp 75.000/kg. para nelayan setempat juga menjelaskan bahwa ketika hasil tangkapan mereka hanya mencapai $200 \mathrm{Kg}$ itu hanya akan cukup untuk modal mereka dalam melaut.

Selain itu, intensitas curah hujan juga berpengaruh bagi para nelayan untuk pergi melaut, ditambah lagi sekarang dengan adanya isu-isu yang muncul bahwa ikan yang beredar di pasaran banyak terdapat ulat di dalam dagingnya. Hal ini membuat merosotnya harga ikan receh seperti ikan kerisi, ikan tamban, 
ikan selar dan yang lain sebagainya sebesar $50 \%$ dari harga sebelumnya, berikut adalah penjelasan dari salah satu responden yang kami wawancarai:

"Jika musim hujan biasanya hanya sebagian nelayan saja yang pergi ke laut, sekitar $40 \%$ saja yang pergi mencari ikan. Ditambah lagi sekarang adanya isu ulat di daging ikan. $\mathrm{Hal}$ ini membuat kami para nelayan sangat kesusahan untuk menjual ikannya karena permintaan ikan di masyarakat menjadi menurun, mau tidak mau kami harus menjual ikannya dengan harga yang murah agar ikan yang kami tangkap terjual habis" (Inul)

Penjelasan dari narasumber diatas menjelaskan bahwa faktor lain yang juga mempengaruhi adalah isu yang berkembang di masyarakat tentang adanya ulat dalam daging ikan. Hal ini tentunya akan membuat minat pembeli menurun dengan begitu pendapatan masyarakat nelayan akan ikut mengalami penurunan. Namun walaupun demikian untuk intensitas hujan sebenarnya tidak begitu mempengaruhi untuk jumlah dan hasil tangkapan ikan, yang membuatnya berpengaruh adalah jumlah dari sedikitnya nelayan yang melaut dan juga pola musim ikan yang berubah. Bahwasannya ketika hujan turun dengan intensitas yang tinggi sebagaian dari maryarakat nelayan enggan untuk pergi melaut, tentunya pendapatan akan ikut menurun karena sedikitnya nelayan yang pergi menangkap ikan. Semantara ikan merupakan kebutuhan penting bagi banyak masyarakat terutama ibu rumah tangga, sehingga permintaan akan ikan setiap harinya pasti ada yang berubah hanya sedikit atau banyaknya permintaan yang ada dipasar, dan tentunya permintaan pasar ini tidak lepas dari dampak yang ditimbulkan oleh perubahan cuaca pada pekerjaan nelayan.

Seolah saling berkaitan antara banyak faktor ini semakin menguatkan bahwa stabilitas harga ikan ditentukan olah banyak hal bukan sebatas besar tidaknya permintaan dari masyarakat dan pasar, pengaruh terbesar yang menjadi faktor penetu naik turunnya harag ikan di pasaran adalah kondisi cuaca yang kerap berubah. Perubahan cuaca ini membawa dampak yang besar bagi kehidupan masyakat nelayan dan juga stabilitas pasar. Ketika permintaan pasar mengalami penurunan ataupun peningkatan maka penghasilan nelayan akan ikut mengalami perubahan baik mengalami penurunan ataupun peningkatan tergantung dengan harga ikan di pasar, begitu juga selanjutnya ketika cuaca mengalami perubahan maka para nelayan akan kesusahan dalam menangkap ikan dan berdampak pada sedikitnya hasil tangkapan mereka yang tidak bisa memenuhi permintaan pasar yang tentunya meningkat, maka harga ikan pun akan mengalami perubahan. Namun walaupun demikian pada beberapa kondisi atau cuaca pera nelayan bisa menangkap ikan seprti biasanya tanpa terkendala oleh cuaca. Dengan kata lain ada saatnya cuaca yang menguntungkan bagi nelayan untuk melaut dan harga ikanpun stabil tidak mengalami penurunan.

Cuaca yang baik untuk nelayan melaut adalah perkisaran antara bulan sepertember hingga bulan februari bagi para nelayan yang memancing. Para nelayan juga menjelaskan bahwa terkadang walaupun ikan mudah di dapat namun ada masanya harga ikan tetap murah tergantung pada permintaan pasar kecuali sotong yang hanya mengalami penurunan paling benyak Rp $2.000 / \mathrm{kg}$. seperti yang di sampaikan oleh responden berikut ini:

"harga ikan pada bulan sekarang cukup sulit karena 


\begin{abstract}
mengalami penurunan, ibaratnya kami para nelayan cukup kesusahan pada bulanbulan sekang terlebih kami para nelayan di sini masih menangkap ikan secara manual. Selain itu ketika kami mendapatkan ikan yang kurang bagus maka harga jualnya juga akan rendah. Ditambah lagi perubahan cuaca yang kerap terjadi, kami disini menyebutnya musim pancaroba" (Jabar).
\end{abstract}

Penjelasan dari responden juga menyebutkan bahwa ketika harga ikan turun, para nelayan tidak memiliki pilihan lain kecuali menjualnya kepada pengepul mereka. Karena dari pihak pengepul mereka tidak mau jika ikan itu di stok dulu untuk beberapa saat. Sehingga ketika harga ikan mengalami penurunan para nelayan akan tetap menjualnya. Alasan lain yang membuat mereka akn tentap menjual ikannya yang mereka dapatkan walau dalam jumlah dan harga yang rendah adalah keperluan hidup sehari-hari dan modal untuk bekerja di esok harinya, karena memang pendapatan mereka tidak bisa di prediksi sebelumnya. Para nelayan juga mengakui bahwa cuaca memang berpengaruh terhadap hasil tangkapan mereka yang kemudian hasil tangkapan akan mempengaruhi stabilitas harga di pasar. Cuaca paling rentan adalah ketika terjadi angin kencang yang disertai oleh gelombang tinggi karena di kondisi seperti ini nelayan memang benar-benar tidak bisa melakukan pekerjaan mereka kerena resiko keselamatannya terlalu tinggi. Pada keadaan ini yang bisa dilakukan oleh masyarkat yang berprofesi sebagai nelayan adalah berdiam diri di rumah menunggu waktu yang baik untuk melakukan pekerjaan mereka yaitu menangkap ikan, apalagi di Desa Kurau kebanyakkan dari masyarakatnya menjadikan profesi nelayan sebagai profesi tunggal mereka, artinya melaut adalah satu-satunya pekerjaan yang mereka lakukakan, sehingga ketika mereka tidak bia melaut maka tidak ada alternatif pekerjaan yang bisa mereka lakukan sementara menunggu cuaca membaik untuk melaut. sehingga perekonomian masyarakatnya juga bergantung penuh dari hasil tangkapan ikan yang mereka dapat. Seperti yang dijelaskan oleh salah satu nelayan yang ada di desa kurau:

"kerena ke laut ini merupakan mata pencaharian tunggal bagi kami, kalian paham tentunya ketika komdisi cuaca sedang tidak baik maka kami tidak emmpunyai pekerjaan alternatif yang bisa dilakukan, jadi mau tidak mau ketika harga murah pun akan tetap kami jual. Walau terkadang kami sama sekali tidak mendapatkan keuntungan, katakanlah hasil dari penjualan kami hanya cukup untuk modal. Bahkan pernah sesekali kami malahan mengalami kerugian, itulah resikonya pengasilan sebagai nelayan tidak pernah menentu seperti gaji orang kantoran". (Erik).

Dari penjelasaan Erik di atas dapat dikatakan bahwa pengaruh dari cuaca terhadap jumlah hasil tangkapan ikan berimbas lansung terhadap perekonomian masyarakatnya, karena nelayan menjadi satu-satunya profesi mereka.bagi Erik sendiri kondisi seperti ini sebenarnya cukup menyulitkan, karena tuntutan perekonomian dan kebutuhan sehari-hari yang tidak bisa di hindari. Begitunya dengan masyarkat lainnya, ketika harga ikan dan pendapatan mereka menurun maka penghasilan mereka akan ikut menurun. Sehingga ketika terjadi penurunan harga ikan ang di sebabkan oleh cuaca pada jangka waktu yang cukup 
panjang akan membuat roda perekonomian masyarkat nelayan mengalami kesulitan, karena memang tidak ada pekerjaan cadangan yang bisa di lakukan ketika cuaca yang kurang baik terjadi, selain pergi ke laut. Namun tentunya pada kondisi cuaca yang benarbenar buruk para nelayan juga tidak bisa memaksakan diri untuk pergi melaut kerena ini beresiko besar untuk keselamatan mereka.

Di sisi lain beberapa nelayan juga mengakui bahwa cuaca memang merupakan penentu bagi mereka dalam melakukan pekerjaan, namun juga pola kerja dan sarana yang mereka gunakan menjadi bagian penting lainnya yang ikut berpengaruh pada hasil tangkapan mereka. Seperti yang di sampaikan oleh suheri dia menyinggung sedikit tentang alat yang mereka gunakan dalam menangkapa ikan.

"kami para nelayan yang ada di kurau ini masih menangkap ikan dengan cara manual, sehingga perubahan cuaca itu sangat besar pengaruhnya. Berbeda dengan dibeberapa daerah lainnya yang sudah menggunakan perelatan yang cukup canggi untuk menangkap ikan. Sehingga hsil tangkapan mereka pun akan berkali lipat lebih banyak, walaupun pada kondisi cuaca yang kurang baik. Sedangkan kami pada kondisi cuaca yang buruk kami tidak bisa memaksakan untuk melaut kerena resiko yang cukup besar bagi kelamatan dan juga pendapatan kam tidak akan terlalu banyak. Tau sendirilah dilaut itu diak ada apa-apa yang bisa melindungi, syukur-syukur kalo ada pulaupulau kecil di sekitar wialayah kami melaut". (Suheri).

Apa yang disampaikan oleh responden ini menjelaskan bahwa selain kondisi fisik dan kendala yang dihadapi secara lansung oleh pera nelayan, peralatan mereka dalam menangkap ikan juga ikut menjadi pertimbangan untuk digunakan ketika cuaca yang kurang baik, mengingat cara dan alat yang digunakan masih manual. Sehingga jika dibandingkan dengan nelayan di beberapa daerah lainnya yang sudah menggunakan peralatan yang lebih canggih dan tidak memiliki ketergantungan yang tinggi terhadap cuaca, hasil tangkapan mereka pun akan jauh lebih sedikit dibandingkan dengan nelayan yang menggunakan perlatan yang lebih modern. Sedikitnya hasil tangkap mereka inilah yang kemudian ikut menurunkan pendapatan mereka dan membuat peningkatan permintaan pada kondisi tertentu (cuaca kurang baik), ketika permintaan pasar meningkat sebenarnya bisa saja nelayan mendapatkan keuntungan yang lebih besar kerena harga ikan dipasar mengalami kenaikan harga, namun resiko yang harus mereka ambil terlalu besar jika tetap melaut di saat kondisi cuaca yang tidak memungkinkan. Tidak hanya sampai pada peralatan manual yang digunakan persoalan lain yang di hadapi oleh para nelayan adalah mengenai ketentuan yang ditetapkan oleh para pengepul ikan, dimana mereka para nelayan harus menjual tangkapan ikan sesegera mungkin dengan kata lain tidak boleh ditampung di rumah sendiri. Hal ini menyebabkan sedikit atau banyak hasil tangkapan yang diperoleh nelayan akan lansung dijual kepada pengepul, dari pada tidak laku sama sekali. hal Inilah yang kemudian juga menyebabkan nelayan mengalami kerugian. Kaitannya dengan cuaca adalah hal semacam ini terjadi ketika cuaca yang sedang buruk dan hal tangkapan iakn mereka sedikit, katakanlah tidak memenuhi target modal. Sehingga sebagian dari nelayan kemudian memutuskan untuk libur melaut dari pada mereka harus mengalami kerugian dalam jumlah yang cukup besar. Walaupun tidak bisa dipungkiri, 
ISSN 1412-2936

EISSN 2549-7308

sebanarnya mereka membutuhkan aliran dana setiap harinya sebagai modal dalam pekerjaan.

Terkait perubahan cuaca, hingga saat ini gelombang tinggi merupakan kendala terbesar yang dihadapi oleh para nelayan di desa kurau. Karena ketika gelombang tinggi dapat dipastikan para nelayan tidak akan turun kelaut, mereka akan menunda proses operasional penangkapan. Sehingga secara garis besar bahwa cuaca memang memiliki pengaruh besar dalam stabilitas harga ikan dan perekonomian masyarakat desa. Perubahan cuaca yang kerap terjadi membuat pasang surut harga ikan dipasaran dan membuat pendapatan masyarakat juga mengalami perubahan. Walupun pada dasarnya nelayan merupakan pekerjaan dengan pengasilan yang tidak menentu, namun dengan adanya perubahan cuaca yang menjadi kendala bagi mereka dalam melakukan pekrjaan ini akan semangkin membuat pendaptan mereka mengalami penuruna pada waktu tertentu. Seperti yang di sampaikan oleh salah satu responden, tidak jauh berbeda dengan apa yang di sampai oleh para responden sebelumnnya, Menu juga menyampaikan bahwa perubahan cuaca yang cukup ekstrim memang memberikan dampak yang kurang baik bagi para nelayan terutama gelombang tinggi dan intensitas hujan dalam jangka waktu lama misalnya lima sampai tujuh hari, maka otomatis pekerjaan nelayan akan tertunda atau mengalami kendala lainnya kerena cuaca yang tidak mendukung.

"saat gelombang tinggi, kami mana bisa pergi melaut seperti biasanya resikonya cukup besar da membahayakan keselamatan. Apalagi terjadi angin kencang, sudah dipastikan kami tidak akan pergi melaut. Pergipun juga percuma, ikan yang didapatkan tidak akan memenuhi target.

\begin{abstract}
Beberapa kami pernah kami tetap melaut pada kondisi cuaca yan kurang baik, hasilnya ikan yang didapatkan tidak benyak. Pahamlah pergi kelaut juga membutuh modal, jika hasilyangkapan tidak banyak modal kami tidak bisa kembali dan mengalami kerugian. Memang pada saat seperti ini permintaan pasar akan meningkat dan harga ikan naik. Tapi kalau saya pribadi tidk mau mengambil resiko karena keselamatan juga di pertahukan pada saat melaut di cuaca buruk. (Menu)
\end{abstract}

Keadaan seperti yang dijelaskan oleh responden diatas memperjelas bahwa antara cuaca, nelayan, dan stabilitas harga ikan mememiliki keterkaitan satu sama lainnya. Pengaruh besar yang diberikan oleh cuaca terhadap kehidupan masyarakat tidak hanya sebatas pekejaan mereka dalam menangkap ikan namun juga pada kondisi perekonomian mereka, karena harga ikan dipasar pun juga berdasarkan pada kondisi cuaca yang terjadi. Nelayan di Desa kurau menyadari bahwa saat ini stabilitas harga ikan sedang terganggu, sehingga gampang sekali mengami perubahan. Hal ini menyebabkan dilema besar yang dihadapi nelayan ketika saat seperti ini, dimana harga ikan mengalami peningkatan atau kenaikan, namun mereka tidak bisa memakasakan diri untuk bekerja menangkap ikan diakrena cuaca yang buruk sehingga tidak memungkinkan bagi mereka untuk pergi melaut, untuk alasan keselamatan resikonya cukup besar jika tetap melaut dengan keadaan gelombang tinggi dan angin deras. Dapt dikatakan dalam satu tahun hanya beberapa bulan saja yang mengutungkan bagi masyarakat nelayan, sisanya hanya cukup memenuhi standar atau terkadang memberikan kerugian. Sebab terkadang ketika hasil tangkapan 
mereka ada, namun dijual dengan harga yang mahal maka tidak jarang masyarakat menurunkan minat mereka dalam membeli ikan denganalasan ekonomis, harga ikan terlalu tinggi pada bulan-bulan yang memeng cukup sulit mendapatkan ikan.

Berdasarkan apa yang telah disampaikan oleh para responden diatas, dapat dilihat bahwa cuaca memilki pengaruh yang besar terhadap kinerjanelayan dan juga stabilitas harga ikan dipasar, karena cuaca juga mempengaruhi musim dari ikan. Masyarakat nelayan jiga menyadari bahwa sebagian besar dari pekrjaan mereka memang mengandalakan kondisi cuaca, jika kondisi cuaca baik maka para nelayan tidak akan mengalami banyak kendala, sadangkan ketika cuaca buruk para nelayan akan mengami lebih banyak kesulitan dalam pekerjaan meraka. Mereka juga tidak bisa memaksakan

\section{KESIMPULAN}

Dari pembahasan diatas dapat disimpulakan bahwa perubahan cuaca yang terjadi memiliki pengaruh besar terhadap stabilitas harga ikan di pasar dan berimbas juga pada kehidupan ekonomi masyarakatanya. Serta pada tahun ini khusus di Desa Kurau untuk harga ikan sendiri mengalami penurunan sebanyak $50 \%$ dari tahun sebelumnya, terutama untuk ikan yang digunakan sebagai bahan dasar produksi kerupuk (getas). Untuk kendala yang dihadapi oleh nelayan, Sampai saat ini gelombang tinggi menjadi kendala utama bagi para nelayan. Selain gelombang tinggi kedala lainnya yang dihadapi nelayan adalah intensitas curah hujan yang tinggi, bulan terang dan angin kencang yang berimas pada hasil tangkapan nelayan. Ketika jumlah tangkapan ikan menurun dan permintaan pasar meningkat maka harga ikan akan naik. Sedangkan untuk kestabilan harga ikan yang hanya mnegalami sedikit keadaan ketika memang kondisi benarbenar tidak memungkinkan bagi mereka untuk melaut karena ini berhubungan dengan kaadaan alam yang tidak bisa mereka atur sesuai keinginan mereka. Terlepas dari bahasan menegnai perubahan cuaca yang berdampak bagi stabilitas harga, peneliti juga menemukan data lapangan bahwa di Desa Kurau sendiri terdapat dua TPI (tempat penampungan ikan), dimana tempat ini merupakan tempat para nelayan menjual hasil ikan yang mereka dapatkan. Inti penting dari pembahasan ini adalah ditemukannya fakta lapangan bahwa perubhan cuaca yang terjadi seperti hujan deras, gelombang tinggi, angin kencang dan juga bulan terang memberiakn dampak kepada stabilitas harga ikan dipasar. Dampak lansung juga dirasakan oleh pera masyarakat yang berprofesi sebagai nelayan baik itu nelayan tangkap, nelayan, bagan dan nelayang pancing

penurunan adalah ikan tenggiri dan sotong yang memang harganya jarang sekali turun drastis. Jadi dari data lapangan yang didapatkan disimpulkan kembai bahwa perubahan cuaca memang memiliki pengaruh yang cukup besar terhdap stabilitas harga ikan dan juga pendapatan nelayan yang ada di desa Kurau. Serta untuk tanggapan dari pemerintah desa setempat masih kurang untuk mengatasi permasalah atau pemberian solusi kepada para nelayan, seperti beberapa kali proposal yang diajukan oleh para nelayan namun tidak di tindak lanjuti. Kehidupan nelayan yang sepenuhnya bergantung pada lau, membuat mereka tidak mempunyai banyak pilihan bekerja untuk mata pencarian lainnya. Bagi mereka melaut merupakan mata pencaharian tunggal. Peningkatan kualitas hidup nelayan diwilayah pesisir juga harus menjadi perhatian penting bagi pemerintah setempat agar menjamin terwujudnya 
ISSN 1412-2936

EISSN 2549-7308

kehidupan sejahtera baik dalam bidang ekonomi, social dan budaya.

\section{SARAN PENELITIAN}

Dalam penelitian ini peneliti hanya membahas mengenai pengaruh cuaca teradap stabilitas harga ikan, sehingga perlu dilakukan penelitihan lanjutan untuk membahasan lanjutan dari permasalahan ini seperti pengaruh terhadap kehidupan ekonomi masyarakat yang disebabkan oleh penurunan harga ikan serta mengenai masyarakat yang berprofesi tunggal sebagai nelayan. Karena yang menerima dampak langsung dari penurunan harga ikan dan juga perubahan cuaca adalah kondisi perekonomian dari masyarakatnya. Akan lebih baik jika penelitian kedepannya di kaji dengan menggunakan pendekatan etnografi sehingga peneliti bisa secara lansung ikut serta dengan apa yang dirasakan olah masyarkat dan tujuan dari penelitian bisa tercapai. Diperlukan juga penelitian lanjutan untuk membahas mengenai dampak kenaikan harga ikan bagi masyarakat luas terutam ibu rumah tangga serta keseimbangan pasar. Agar pembahasan mengenai stabilitas ini bisa dijelaskan secara tuntas. Jika dimungkinkan untuk diteliti ada beberapa hal menarik lainnya yang bisa diteliti yaitu tentang bagaimana cara masyarakat diwilayah pesisir mengatasi perubahan cuaca yang terjadi termasuk juga krisis perekonomian pada jangka waktu tertentu, misalnya ketika mereka tidak bekerja dalam kurun waktu yang cukup lama, sedangkan mereka hanya bermata pencarian tunggal. Kajian untuk mengetahui sikap masyarakat dalam menjalani kehidupan mereka sebagai nelayan di wilayah pesisir.

DAFTAR PUSTAKA

Azizi, E. I. K. Putri, dan A. Fahrudin. 2017. Analisis Faktor-Faktor Yang Mempengaruhi Perubahan Pendapatan Nelayan Akibat Variabilitas Iklim. J. Sosek KP:225233.

Book, F. A. O. Y. (2014). No Title, 2012, $1-10$.

Irwanto, Hasip. 2015. Analisis Strategi Sosial Ekonomi Nelayan Terhadap Dampak Fenomena Cuaca Buruk, Terang Bulan, Dan Kenaikan Harga Bbm Di Desa Sotabar Kecamatan Pesean Kabupaten Pemakasan. Skripsi. Program Sarjana Universitas Muhammadiyah Malang. Malang.

Nelayan, T., \& Kecamatan, D. I. (2016). Analisis Faktor-Faktor Yang Mempengaruhi Hasil, I(1).

Puluhulawa, J. A. Rauf, Dan A. Halid. 2016. Analisis Faktor-Faktor Yang Mempengaruhi Hasil Tangkapan Nelayan Di Kecamatan Bilato Kabupaten Gorontalo. Jurnal Ilmiah Agribisnis: 44-50

Ulfa, M. 2018. Persepsi Masyarakat Nelayan Dalam Menghadapi Perubahan Iklim (Ditinjau Dalam Aspek Sosial Ekonomi), Jurnal Pendidikan Geografi: 41-49 